Article

\title{
Construction Cost of Green Building Certified Residence: A Case Study in Taiwan
}

\author{
Chen-Yi Sun ${ }^{1, *} \mathbb{C}$, Yin-Guang Chen ${ }^{1}$, Rong-Jing Wang ${ }^{2}$, Shih-Chi Lo ${ }^{2}$, Jyh-Tyng Yau ${ }^{2}$ and \\ Ya-Wen $\mathrm{Wu}^{3}$ \\ 1 Department of Land Economics, National Chengchi University, Taipei 11605, Taiwan; \\ nyyyankee0704@gmail.com \\ 2 Architecture and Building Research Institute, Ministry of the Interior, New Taipei City 23143, Taiwan; \\ jing@abri.gov.tw (R.-J.W.); losc@abri.gov.tw (S.-C.L.); jyhtyng@abri.gov.tw (J.-T.Y.) \\ 3 Department of Electronic Banking, Land Bank of Taiwan, Taipei 10047, Taiwan; judywu0201@yahoo.com.tw \\ * Correspondence: justin.sun.tw@gmail.com; Tel.: +886-909-619-196
}

Received: 28 February 2019; Accepted: 9 April 2019; Published: 12 April 2019

check for updates

\begin{abstract}
The green building certification system of Taiwan, EEWH (Ecology, Energy Saving, Waste Reduction and Health), has been in operation for more than 20 years (since 1999). In order to understand the relationship between green building certification and the construction costs of residential buildings, this study obtained 37 green building-certified residential cases and 36 general residential cases available from public information and conducted a comparative analysis. The results of this study showed that the average construction cost of a green building certification residential building was only $1.58 \%$ higher than a general residential building, indicating that green building certification does not require a large increase in costs. However, for residential buildings, achieving a high-grade (gold-grade or diamond-grade) green building certification means an increase of $6.7 \%$ to $9.3 \%$ in construction costs. This shows that the pursuit of higher levels of green building certification does require higher construction costs. In addition, the results of this study can not only provide important references for the government in making green building policies, but also offer a practical strategy for developers for decision-making.
\end{abstract}

Keywords: policy; sustainable development; environmental friendly; evaluation system

\section{Introduction}

In order to practice the goal of sustainable development, several countries launched green building promotion activities by the end of the 20th century; moreover, many countries have developed various evaluation systems and certification systems for green buildings [1-4], such as the BREEAM (Building Research Establishment's Environmental Assessment Method) in the UK in 1990 [1,3-7]; LEED (Leadership in Environmental and Energy Design Leadership) in the USA in 1998 [1,2,4,7-9]; EEWH (Ecology, Energy Saving, Waste Reduction and Health) in Taiwan in 1999 [10-16]; the Comprehensive Assessment System for Built Environment Efficiency (CASBEE) in Japan in 2001 [7,15]; the GB TOOL in Canada in 2005 [1,7]; the Green Mark in Singapore in 2005 [1,4,14,15,17,18]; the Evaluation Standard Green Building (ESGB) in China in 2006 [1,2,18,19]; the Code for Sustainable Homes (CSH) for residential buildings in the UK in 2008 [2]; and the Green Star in Australia in 2015 [1,8,9,19,20]. In other words, in the past two decades, many green building certification systems have emerged, and numerous green buildings have been built.

Ample studies in the literature have raised the benefits of green buildings, such as energy savings, emissions savings, water savings, operations and maintenance saving, and productivity and health benefits, which conventional buildings do not have $[9,15,18,21-25]$. Therefore, in terms of revenue 
considerations, green buildings are also worthy of investment $[9,18,22,23,26]$. However, although green buildings have many advantages, the additional construction costs of green buildings are also very important issues.

According to the results of a study in Singapore, the market premium of green building certificated buildings is about $10 \%$ at the resale stage, compared to about $4 \%$ during the pre-sale stage [27]. As energy efficiency is beneficial to those who use the building, it does not produce any direct benefits for the building developer. Therefore, a better strategy is to encourage construction developers to reduce the additional cost of residential buildings in order to achieve green building certification through planning and design.

Regarding the construction cost of a green building, according to relevant research results, the extra costs of a green building for office buildings in Israeli are $4.33 \%-11.6 \%, 75 \%-96 \%$ of these costs are spent on energy saving improvements [22]. One paper presented a comprehensive cost comparative analysis of residential housing in China, which showed that the incorporation of green building systems such as energy-efficient appliances, equipment, and lighting caused the construction costs to increase by $10.77 \%$ compared to traditional buildings [28]. Another literature study of China's green building case analysis showed that the average green premium percentage of the overall project investment in China is $10.9 \%$ (Hotel $8.5 \%$, residential building 10.3\%, office 13.9\%) [29]. In addition, a green building study in China pointed out that the incremental costs of the energy efficiency technology application (EETA) accounted for a large proportion (more than $50 \%$ ) of the total incremental costs of green buildings, even though the EETA on green buildings could bring incremental economic benefits as well as environmental benefits [18].

Although many studies have confirmed that the cost of green buildings is more expensive than general buildings, from the conclusions of a study on the US "LEED" evaluation system in the design phase to confirm the goals of sustainable design and the budget of the building, building a green certified building (library, laboratory, and academic classroom projects) does not necessarily require an increase in budget [30]. In addition, according to a literature study in the UK [31], consultants generally think that more energy efficient and environmentally friendly buildings have an extra cost about $5 \%$ to $15 \%$; however, as long as the design is appropriate, the additional costs of more energy efficient and environmentally friendly buildings should not be more than $1 \%$ when compared with a general building. Therefore, the misconception that green buildings cost more in capital cost terms should start to be dispelled.

According to the above literature analysis, some studies focus on the establishment mechanism and comparative analysis of green building evaluation systems; some of the research aims to discuss the energy conservation, water saving, and economic benefits of green buildings; some articles focus on the analysis of the differences of construction cost between green buildings and general buildings.

The green building certification system of Taiwan, EEWH, has been in operation for more than 20 years (since 1999). There are thousands of cases of green certified buildings that meet the green building objectives of ecology, energy saving, waste reduction, water conservation, and a healthy environment. Although there have been many studies on green building and sustainable development in Taiwan [10,13-15,32-37], there are still very limited studies on the green building costs of residential buildings in Taiwan. Since most of the literature is based on the cost of the entire building [30,31,38-41], this study also uses similar data to facilitate the comparison between the research results and the literature. Therefore, the aim of this paper was to analyze the difference in construction costs between green buildings and general buildings by the green residential building case studies. The results of this research can not only become a reference source for future research on the cost of green buildings across nations or regions, but also can lead to strategies for making green property projects more cost effective in the Taiwanese market.

\section{Methods and Materials}

In order to clarify the construction cost differences between green building certified residences and general residences in Taiwan, this study collected 37 cases of residential buildings with green building 
certification and 36 cases of general residential buildings through government public information websites and architectural professional magazines (Table 1; Figure 1). In order to ensure the credibility of the results of this study, the study did not use any non-public information, but used Taiwan's most open and fair data for analysis. In addition, many of the studies on green building cost analysis have focused on planning and design costs, construction costs, management costs, or maintenance costs. In order to avoid confusion, the cost of all cases in this study included planning and design fee, construction cost, landscape cost, and interior decoration cost. In order to avoid buildings with different completion periods and the difference in construction costs due to differences in material prices and wages, the building samples selected in this study were completed in the same period. All cases used in this study were completed from 2010 to 2018. According to government statistics, the average annual growth rate of the consumer price index during the period from 2010 to 2018 is only $1.05 \%$, which is a period of stable prices. Therefore, this study does not adjust the case for different years [42].

Table 1. Background information on the green building certification residential cases and general residential cases of this study.

\begin{tabular}{crrrrrr}
\hline \multirow{2}{*}{$\begin{array}{c}\text { Data } \\
\text { Information }\end{array}$} & \multicolumn{2}{c}{ General Residence (by 36 Cases) } & \multicolumn{2}{c}{ Green Residence (by 37 Cases) } \\
\cline { 2 - 7 } & $\begin{array}{c}\text { Total Floor } \\
\text { Area } \mathbf{( m}^{2} \text { ) }\end{array}$ & $\begin{array}{c}\text { Total Project } \\
\text { Cost (USD) }\end{array}$ & $\begin{array}{c}\text { Unit Area } \\
\text { Cost (USD) }\end{array}$ & $\begin{array}{c}\text { Total Floor } \\
\text { Area (m } \mathbf{~}^{\mathbf{}} \text { ) }\end{array}$ & $\begin{array}{c}\text { Total Project } \\
\text { Cost (USD) }\end{array}$ & $\begin{array}{c}\text { Unit Area } \\
\text { Cost (USD) }\end{array}$ \\
\hline Average & 7966 & $11,435,341$ & 1529 & 32,204 & $47,515,607$ & 1553 \\
Maximum & 48,788 & $70,933,474$ & 2821 & 122,097 & $144,235,293$ & 2289 \\
Minimum & 302 & 298,313 & 704 & 2085 & $4,366,650$ & 959 \\
Median & 2157 & $3,405,971$ & 1313 & 22,596 & $35,507,250$ & 1571 \\
Standard & 11,129 & $16,985,225$ & 602 & 27,557 & $35,847,457$ & 332 \\
Deviation & & & & & & \\
\hline
\end{tabular}

Data sources: [43-45].

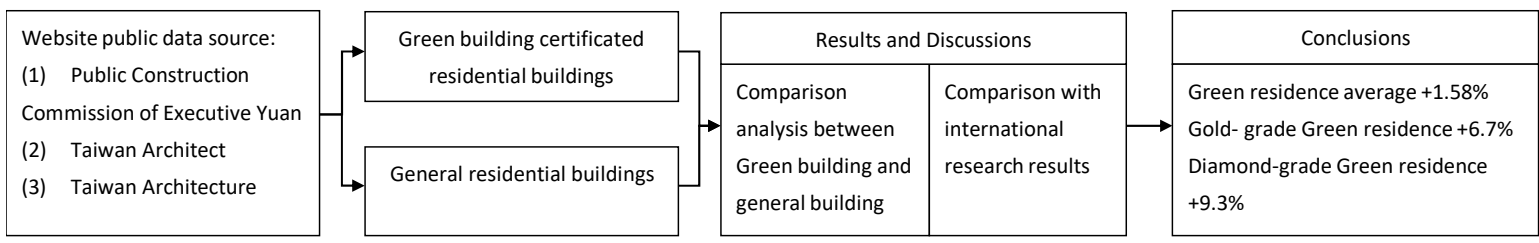

Figure 1. Flow chart of this study.

According to the basic statistics of all of the cases used in this study (Table 2), the overall building scale and total construction cost of the green building case were relatively higher than the general building, but the difference of the average cost per square meter was small (only $24 \mathrm{USD} / \mathrm{m}^{2}$ ). The above results are mainly due to the background of the green building policy in Taiwan as well as the research restrictions on the collection of data related to the comparison of green building costs in Taiwan. The Taiwanese government requires that most public buildings, especially those built by the government (such as public housing, public schools, and government buildings), are obliged to obtain green building certification. In addition, for residential buildings built by private developers, there is no mandatory requirement for green building certification. As for the residential buildings built by private developers with green building certification, it is rare to disclose the construction price and relevant basic information based on trade secrets and other concerns. As a result, most of the green building certification residential cases that the study was able to collect were public housing projects built by the government.

Regarding the data distribution state, in the sample of residential buildings with green building certification in this study, the maximum construction cost per $\mathrm{m}^{2}$ was $\$ 2289$, with a minimum of $\$ 959$ and an average of $\$ 1553$; furthermore, all green residential samples showed a normal distribution (Figure 2). In the general residential building sample in this study, the maximum construction cost 
per $\mathrm{m}^{2}$ was $\$ 2821$, with a minimum of $\$ 704$ and an average of $\$ 1529$; moreover, the distribution of all general residential samples was relatively discrete (Figure 3).

Table 2. Related research results of extra increase in construction costs of green building certificated buildings.

\begin{tabular}{cccc}
\hline References & Country & Building Type & Extra Construction Costs \\
\hline$[31]$ & UK & housing, commercial, industrial & $\begin{array}{c}5 \%-15 \% \text { or less than } 1 \% \\
\text { hotel } 8.5 \% \text {, residential } \\
\text { building } 10.3 \%, \text { office } 13.9 \% \\
\text { (Average } 10.9 \%)\end{array}$ \\
{$[29]$} & China & hotel, residential building, office & $10.77 \%$ \\
{$[28]$} & USA & residential housing & $0.66 \%-6.5 \%$ \\
{$[46]$} & USA & office, school & $0 \%$ \\
{$[30]$} & USA & library, laboratory, academic classroom & $2 \%-3 \%$ \\
{$[47]$} & USA & bank & $0 \%$ \\
{$[48]$} & New Zealand & office & $4.33-11.6 \%$ \\
{$[22]$} & Israel & office & \\
\hline
\end{tabular}

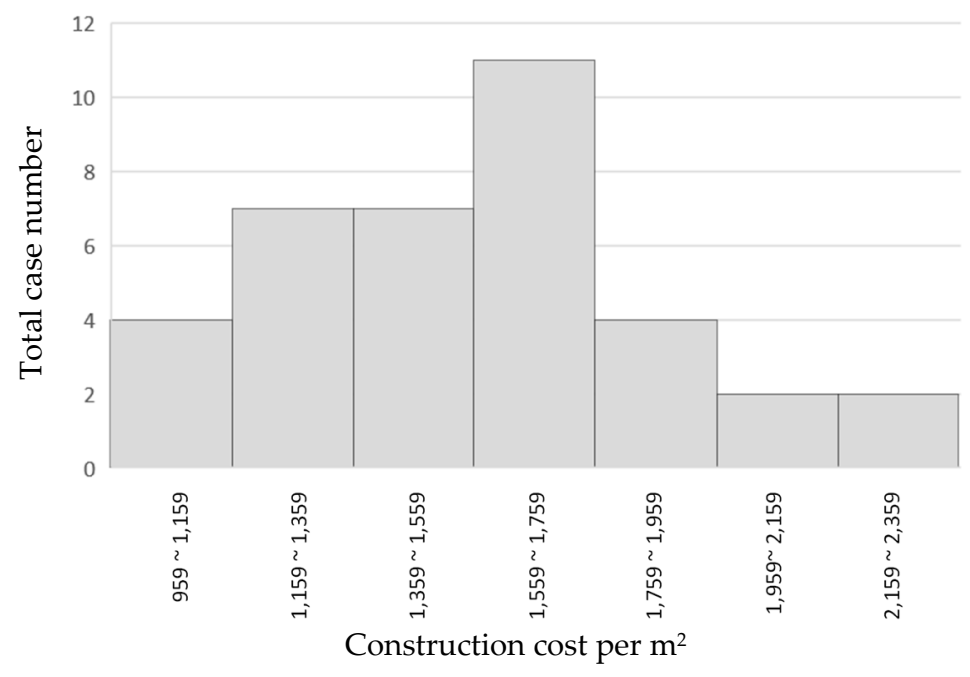

Figure 2. Number of green building certified residences in different construction cost ranges.

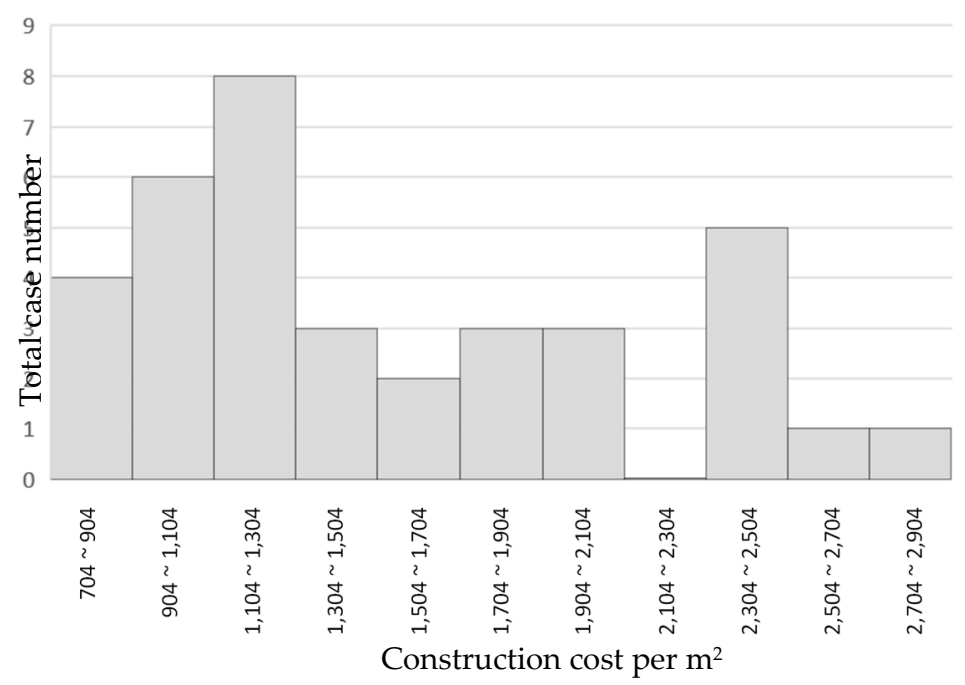

Figure 3. Number of general residences in different construction cost ranges. 


\section{Results and Discussions}

\subsection{Average Construction Cost of Green Residences}

Since many related research results show that buildings with green building certification may increase construction costs (Table 2), people have the impression that a green building certified residential building may require extra construction costs to strengthen the building's materials and equipment to meet the high requirements of green building certification in Taiwan. Therefore, recognition of "the construction cost of green building certified residence is relatively high" has always been a stereotype believed by people.

Due to the difference in requirements of the building base and building capacity, the means for each building case to meet the green building certification standards are slightly different. Therefore, in some cases, under the environmental conditions of the base or the setting of the building function, the requirements for green building certification can be met at a lower construction cost. However, in some cases, the goal of obtaining a green building certification must be achieved with a more expensive strategy. The average construction cost (USD per $\mathrm{m}^{2}$ ) of green building certified residence cases was only $1.58 \%$ higher than general residences in this study (Table 3 ). The results of this study were similar to the research in the UK (less than 1\%) [31] and in the USA (below 2\%) [47], which means that environmentally friendly buildings are not necessarily accompanied by more expensive construction costs. According to the results of one study, which developed an optimization algorithm to derive the minimum score for a desired green building certification level at minimal cost in the US [39], through analysis, planning, and design, there are many strategies and ways for building residences to achieve the green building certification standard.

Table 3. Average cost and standard deviation data of each level of green building certified residences.

\begin{tabular}{ccccc}
\hline Grade (cases) & $\begin{array}{c}\text { Average } \\
\text { (USD) }\end{array}$ & $\begin{array}{c}\text { Standard } \\
\text { Deviation (USD) }\end{array}$ & $\begin{array}{c}\text { Difference (Compared with the } \\
\text { Average of Green Building } \\
\text { Certified Residences, USD 1553) }\end{array}$ & $\begin{array}{c}\text { Difference (Compared with } \\
\text { the Average of General } \\
\text { Residences, USD 1529) }\end{array}$ \\
\hline Diamond (1) & 1632 & - & $5.1 \%$ & $6.7 \%$ \\
Gold (15) & 1671 & 377 & $7.6 \%$ & $9.3 \%$ \\
Silver (20) & 1476 & 286 & $-4.9 \%$ & $-3.4 \%$ \\
Bronze (0) & - & - & - & - \\
Qualified (1) & 1238 & - & $-20.3 \%$ & $-19.0 \%$ \\
All graded (37) & 1553 & 333 & $0.0 \%$ & $1.58 \%$ \\
\hline
\end{tabular}

\subsection{Construction Cost of Green Residences in Different Grades of Green Building Certification}

In addition, in terms of the construction cost comparison between residential buildings with different grades of green building certification, the construction costs of buildings that have obtained silver-grade and qualified-grade green building certification is lower than the average value of all green certification buildings. However, the results of this study also showed that the average construction cost of a residential case with a silver-grade green building certification $\left(1476 \mathrm{USD} / \mathrm{m}^{2}\right)$ was lower than the average construction cost of a general residence $\left(1529 \mathrm{USD} / \mathrm{m}^{2}\right)$. This means that medium-grade green residential buildings do not have significantly higher construction costs.

In addition, the construction cost per $\mathrm{m}^{2}$ of obtaining gold-grade and diamond-grade green building-certified residential buildings was about $7.6 \%$ and $5.1 \%$ higher than the average value of all green building certificated residences (Table 3). This shows that the pursuit of higher levels of green building certification does require a higher construction cost.

The results of this analysis confirmed that only high-grade (gold- and diamond-grade) green building certification residences will inevitably require higher construction costs. This phenomenon is derived from the high-grade green building certification of residential buildings because it is impossible for building designers and architects to avoid adding additional construction costs in order to enhance the quality of building greening, use high-efficiency energy-saving and water-saving equipment, 
or increase the use of environmentally-friendly building materials. Therefore, for developers, the pursuit of the appropriate level of building certification is the best strategy.

\subsection{Total Construction Cost of Green Residences of Different Building Sizes}

Buildings with a higher total floor area have a higher total project cost. However, according to the results of this study, there was no significant difference in the total project cost trend as the building size increased, regardless of whether the building was certified by a green building evaluation system (Figure 4). Moreover, the construction cost per $\mathrm{m}^{2}$ for residential buildings of different sizes was also different depending on the case. According to the results of this study, no correlation was found between the construction cost per $\mathrm{m}^{2}$ and the size of the building, either in the green building certified residences or general residences (Figure 5). In fact, there are many key factors affecting the construction cost of residences, and green building certification is only one of these factors.

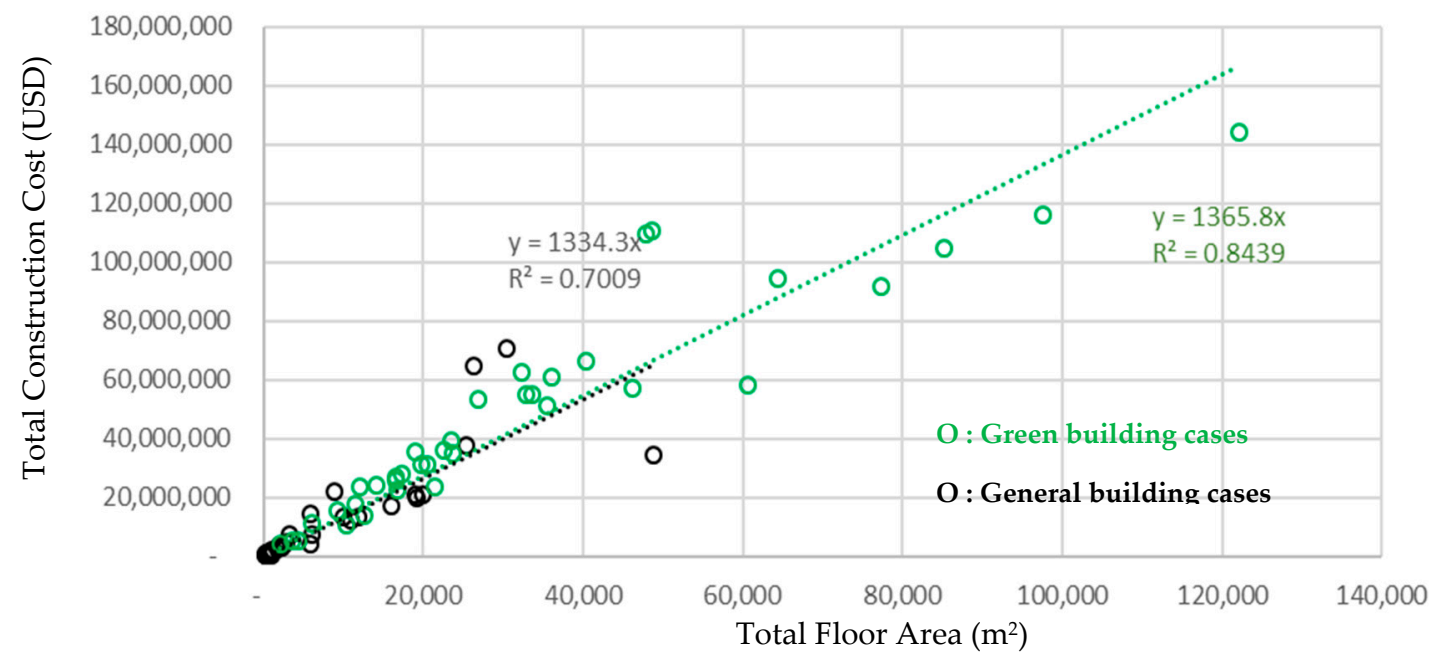

Figure 4. Correlation between Building Scale (Total Floor Area) with Total Construction Cost (USD) of green building certified residences and general residences.

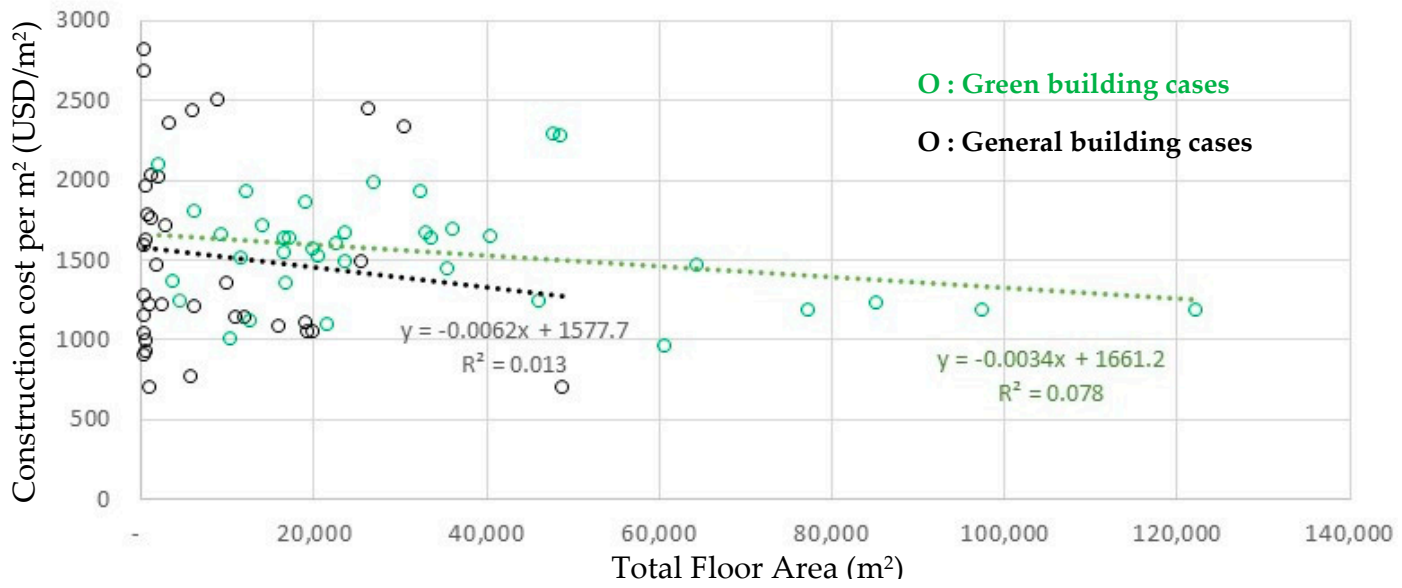

Figure 5. Correlation between Building Scale (Total Floor Area) with Cost per $\mathrm{m}^{2}\left(\mathrm{USD} / \mathrm{m}^{2}\right)$ of green building certified residences and general residences.

\subsection{The Relation between Construction Cost of Residences with a Green Building Evaluation System}

The construction cost of a new residential building comes from four major components: planning and design fees; building construction; landscape; and interior decoration. In Taiwan, planning and construction costs are usually combined into the building's construction budget. Therefore, as long as the planning and design fees are not reduced, the designers and architects are willing to work hard to 
make the building meet the green building certification standards and obtain certification without increasing the total budget. Therefore, the results of this study were quite reasonable and the difference between the average construction cost of a green certified building and the average construction cost of a typical residential building was small.

In order to reduce the additional construction costs added by the green building certification, Taiwan's green building evaluation system was developed with the aim of enabling designers and architects to adopt a planning and design strategy to enhance the building's energy efficiency and environmental protection functions. Therefore, the threshold for obtaining a medium-level green building certification is not high.

According to the results of this study (Table 3), the silver-grade green building certification standard is an important demarcation. According to the analysis of this study, the green building certification level is higher than the silver (gold and diamond) cases, and the construction cost is usually higher than the average of all cases.

Due to the difficulty of obtaining data, this study only analyzed limited data. The green building certification residential building cases obtained in this study are mostly concentrated on the silver and gold levels. Therefore, the clarification of the relationship between the highest and lowest green building certification levels and construction costs is restricted by a lack of relevant evidence in this study.

\section{Conclusions}

In order to understand whether a residential building with green building certification required higher construction costs, this study obtained 37 green building certified residential cases and 36 general residential cases from public information and conducted a comparative analysis. The results of this study showed that the average construction costs of green building certified residences were only $1.58 \%$ higher than the general residences and also indicated that the green building certification did not require a large increase in costs. Compared to the reduction in the maintenance and management costs derived from the energy-saving and water-saving benefits of green buildings, the slightly increased construction costs were even less significant. Therefore, the results of this study confirmed that obtaining a mid-grade green building certification was a good choice for developers to achieve both environmental protection and investment benefits.

In order to reduce the additional construction costs added by the green building certification, Taiwan's green building evaluation system, EEWH, was developed with the aim of enabling designers and architects to adopt a planning and design strategy (such as adjusting the building orientation, using natural ventilation and lighting to reduce building power consumption) to enhance the building's energy efficiency and environmental protection functions. However, for residential buildings that require high-grade green building certification, it is impossible to avoid increasing the construction costs.

The results of this study have also proven that to achieve high-grade green building certification, expensive construction costs must be paid. For residential buildings, achieving a high-grade (goldor diamond-grade) green building certification means an increase of $6.7 \%$ to $9.3 \%$ in construction costs. In addition, the highest level of green building certification often requires more complex equipment to achieve energy and water saving requirements, which means higher management and maintenance costs and equipment renewal costs in the future. Therefore, unless there are very specific needs or reasons, it is better for developers and users to obtain the appropriate level of green building certification within a reasonable budget. In other words, there is no need to increase excessive construction costs in pursuit of the highest level of green building certification.

Although many studies have analyzed the relationship between green building certification and construction costs, the reference value of these research results has declined due to differences in the individual research topics (such as building types) and the environmental, social, and economic differences between the research areas. According to the conclusions of this study, the average construction cost $\left(\right.$ per $\mathrm{m}^{2}$ ) of green building certified residences is $1.58 \%$ higher than that of general 
residences in Taiwan. Although the relevant research results show that the additional construction cost of buildings with green building certification is greater than $10 \%$, the conclusions of this study are similar to some related research results, which proves that green buildings do not necessarily increase many construction costs.

This study explored the relationship between green building certification and the construction costs for residential buildings in Taiwan. In addition to providing basic data for researching green building residential cases, the results of this study can also provide an important reference for developers in practical decision-making. Finally, we recommend that future researchers, in addition to continuing to focus on the construction cost analysis of green building in various countries, also try to propose strategies to reduce the construction price of green building, such as green building materials (e.g., bio-based building products [49]), ecological engineering [50], and sustainable maintenance and management [51].

In addition, since the data of the cost of decomposing construction is more helpful to understand the difference between the green building certification building and the general building, it is recommended that future studies use the breakdown costs instead of total costs to provide more valuable research results.

Author Contributions: C.-Y.S. contributed to the conceptual design of the study, data collection, drafting the article, and final approval. Y.-G.C. contributed to the conceptual design of the study, data collection, and drafting the article. R.-J.W. contributed to the conceptual design of the study and final approval. S.-C.L. contributed to the conceptual design of the study and final approval. J.-T.Y. contributed to the conceptual design of the study and final approval. Y.-W.W. contributed to the final approval.

Funding: This research was funded by the Architecture and Building Research Institute of the Ministry of the Interior, grant number 107301070000G0010.

Acknowledgments: The support of the Architecture and Building Research Institute of the Ministry of the Interior is gratefully acknowledged.

Conflicts of Interest: The authors declare no conflict of interest.

\section{References}

1. Ding, Z.; Fan, Z.; Tam, V.W.Y.; Bian, Y.; Li, S.; Illankoon, I.M.C.S.; Moon, S. Green building evaluation system implementation. Build. Environ. 2018, 133, 32-40. [CrossRef]

2. Zhang, Y.; Wang, J.; Hu, F.; Wang, Y. Comparison of evaluation standards for green building in China, Britain, United States. Renew. Sustain. Energy Rev. 2017, 68, 262-271. [CrossRef]

3. Cole, R.J. Emerging trends in building environmental assessment methods. Build. Res. Inf. 1998, 26, 3-16. [CrossRef]

4. Crawley, D.; Aho, I. Building environmental assessment methods: Applications and development trends. Build. Res. Inf. 1999, 27, 300-308. [CrossRef]

5. Haapio, A.; Viitaniemi, P. A critical review of building environmental assessment tools. Environ. Impact Assess. Rev. 2008, 28, 469-482. [CrossRef]

6. Ding, G.K.C. Sustainable construction-The role of environmental assessment tools. J. Environ. Manag. 2008, 86, 451-464. [CrossRef] [PubMed]

7. Ali, H.H.; Al Nsairat, S.F. Developing a green building assessment tool for developing countries-Case of Jordan. Build. Environ. 2009, 44, 1053-1064. [CrossRef]

8. He, Y.; Kvan, T.; Liu, M.; Li, B. How green building rating systems affect designing green. Build. Environ. 2018, 133, 19-31. [CrossRef]

9. Miller, N.; Spivey, J.; Florance, A. Does Green Pay Off? J. Real Estate Portf. Manag. 2008, 14, 385-400. [CrossRef]

10. Chuang, H.W.; Lin, H.T.; Ho, M.C. The Eco-Community Evaluation System of Taiwan: An Introduction to EEWH-EC. Appl. Mech. Mater. 2011, 71-78, 3466-3469. [CrossRef]

11. Huang, K.-T.; Huang, W.-P.; Lin, T.-P.; Hwang, R.-L. Implementation of green building specification credits for better thermal conditions in naturally ventilated school buildings. Build. Environ. 2015, 86, 141-150. [CrossRef] 
12. Liang, H.-H.; Chen, C.-P.; Hwang, R.-L.; Shih, W.-M.; Lo, S.-C.; Liao, H.-Y. Satisfaction of occupants toward indoor environment quality of certified green office buildings in Taiwan. Build. Environ. 2014, 72, $232-242$. [CrossRef]

13. Yang, K.-H.; Hwang, R.-L. An improved assessment model of variable frequency-driven direct expansion air-conditioning system in commercial buildings for Taiwan green building rating system. Build. Environ. 2007, 42, 3582-3588. [CrossRef]

14. Kuo, C.-F.J.; Lin, C.-H.; Hsu, M.-W. Analysis of intelligent green building policy and developing status in Taiwan. Energy Policy 2016, 95, 291-303. [CrossRef]

15. Chang, K.-F.; Chou, P.-C. Measuring the influence of the greening design of the building environment on the urban real estate market in Taiwan. Build. Environ. 2010, 45, 2057-2067. [CrossRef]

16. Khoshbakht, M.; Gou, Z.; Lu, Y.; Xie, X.; Zhang, J. Are green buildings more satisfactory? A review of global evidence. Habitat Int. 2018, 74, 57-65. [CrossRef]

17. Gou, Z.; Lau, S.S.-Y.; Prasad, D. Market readiness and policy implications for green buildings: Case study from Hong Kong. J. Green Build. 2013, 8, 162-173. [CrossRef]

18. Liu, Y.; Guo, X.; Hu, F. Cost-benefit analysis on green building energy efficiency technology application: A case in China. Energy Build. 2014, 82, 37-46. [CrossRef]

19. Ye, L.; Cheng, Z.; Wang, Q.; Lin, W.; Ren, F. Overview on Green Building Label in China. Renew. Energy 2013, 53, 220-229. [CrossRef]

20. Doan, D.T.; Ghaffarianhoseini, A.; Naismith, N.; Zhang, T.; Ghaffarianhoseini, A.; Tookey, J. A critical comparison of green building rating systems. Build. Environ. 2017, 123, 243-260. [CrossRef]

21. Edwards, B. Benefits of green offices in the UK: Analysis from examples built in the 1990s. Sustain. Dev. 2006, 14, 190-204. [CrossRef]

22. Gabay, H.; Meir, I.A.; Schwartz, M.; Werzberger, E. Cost-benefit analysis of green buildings: An Israeli office buildings case study. Energy Build. 2014, 76, 558-564. [CrossRef]

23. Lützkendorf, T.; Lorenz, D. Sustainability in property valuation: Theory and practice. J. Prop. Invest. Financ. 2008, 26, 482-521. [CrossRef]

24. Ries, R.; Bilec, M.M.; Gokhan, N.M.; Needy, K.L. The Economic Benefits of Green Buildings: A Comprehensive Case Study. Eng. Econ. 2006, 51, 259-295. [CrossRef]

25. Park, J.; Yoon, J.; Kim, K.-H. Critical Review of the Material Criteria of Building Sustainability Assessment Tools. Sustainability 2017, 9, 186. [CrossRef]

26. Aroul, R.; Hansz, J.A. The Value of "Green:" Evidence from the First Mandatory Residential Green Building Program. J. Real Estate Res. 2012, 34, 27-49. [CrossRef]

27. Deng, Y.; Wu, J. Economic returns to residential green building investment: The developers' perspective. Reg. Sci. Urban Econ. 2014, 47, 35-44. [CrossRef]

28. Kim, J.-L.; Greene, M.; Kim, S. Cost Comparative Analysis of a New Green Building Code for Residential Project Development. J. Constr. Eng. Manag. 2014, 140, 05014002. [CrossRef]

29. Zhang, X.; Platten, A.; Shen, L. Green property development practice in China: Costs and barriers. Build. Environ. 2011, 46, 2153-2160. [CrossRef]

30. Morris, P.; Matthiessen, L.F. Budgeting Green: A Comprehensive Methodology. AACE Int. Trans. 2005, ES61-ES64. Available online: https://scholar.google.com/scholar?hl=en\&as_sdt=0\%2C5\&q=Morris\%2C+P. $\% 2 \mathrm{C}+\% 26+$ Matthiessen $\% 2 \mathrm{C}+\mathrm{L} . \mathrm{F} .+\% 282005 \% 29 .+$ Budgeting + green $\% 3 \mathrm{~A}+\mathrm{A}+$ comprehensive+methodolo gy.+AACE+International+Transactions.+ES61\%E2\%80\%93ES64.\&btnG= (accessed on 26 March 2019).

31. Bartlett, E.; Howard, N. Informing the decision makers on the cost and value of green building. Build. Res. Inf. 2000, 28, 315-324. [CrossRef]

32. Sun, C.-Y.; Li, T.-C.; Chen, Y.-Y.; Wu, T.-C. Smart and Ecological Community Assessment Indicator System of Taipei City. J. Archit. 2018, 106_S, 41-54. [CrossRef]

33. Sun, C.Y. The Thermal Influence of Green Roofs on Air Temperature in Taipei City. Appl. Mech. Mater. 2011, 44-47, 1933-1937. [CrossRef]

34. Sun, C.Y.; Lee, K.P.; Lin, T.P.; Lee, S.H. Vegetation as a Material of Roof and City to Cool down the Temperature. Adv. Mater. Res. 2012, 461, 552-556. [CrossRef]

35. Teng, C.-C.; Horng, J.-S.; Hu, M.-L.; Chien, L.-H.; Shen, Y.-C. Developing energy conservation and carbon reduction indicators for the hotel industry in Taiwan. Int. J. Hosp. Manag. 2012, 31, 199-208. [CrossRef] 
36. Sun, C.Y.; Lin, Y.J.; Sung, W.P.; Ou, W.S.; Lu, K.M. Green Roof as a Green Material of Building in Mitigating Heat Island Effect in Taipei City. Appl. Mech. Mater. 2012, 193-194, 368-371. [CrossRef]

37. Sun, C.-Y.; Chen, Y.-A.; Zhang, X. Key Factors in the Success of Eco-Communities in Taiwan's Countryside: The Role of Government, Partner, and Community Group. Sustainability 2019, 11, 1208. [CrossRef]

38. Cole, R.J. Editorial: Cost and Value in Building Green. Build. Res. Inf. 2000, 28, 304-309. [CrossRef]

39. Park, J.-Y.; Choi, S.-G.; Kim, D.-K.; Jeong, M.-C.; Kong, J.-S. Credit Optimization Algorithm for Calculating LEED Costs. Sustainability 2017, 9, 1607. [CrossRef]

40. Shazmin, S.A.A.; Sipan, I.; Sapri, M. Property tax assessment incentives for green building: A review. Renew. Sustain. Energy Rev. 2016, 60, 536-548. [CrossRef]

41. Zalejska-Jonsson, A.; Lind, H.; Hintze, S. Low-energy versus conventional residential buildings: Cost and profit. J. Eur. Real Estate Res. 2012, 5, 211-228. [CrossRef]

42. Directorate General of Budget, Accounting and Statistics of Executive Yuan The Average Annual Growth Rate of the Consumer Price Index. Available online: https:/www.stat.gov.tw/ct.asp?xItem=35375\&CtNode= $487 \& \mathrm{mp}=4$ (accessed on 26 March 2019).

43. Public Construction Commission of Executive Yuan, Government Buildings and Public Construction Projects Inquiry System. Available online: https://web.pcc.gov.tw/tps/pss/tender.do?method=goSearch\&searchMod e=common\&searchType=advance\&searchTarget=ATM (accessed on 26 March 2019).

44. The Journal of The National Association of Architects, R.O.C.T. Taiwan Architect. Available online: http://www.twarchitect.org.tw/early/ (accessed on 26 March 2019).

45. Magazine, T.A.R. Taiwan Architecture. Available online: http://www.ta-mag.net/ta/index.php (accessed on 26 March 2019).

46. Kats, G.H. Green Building Costs and Financial Benefits; Massachusetts Technology Collaborative: Westborough, MA, USA, 2003.

47. Mapp, C.; Nobe, M.; Dunbar, B. The Cost of LEED-An Analysis of the Construction Costs of LEED and Non-LEED Banks. J. Sustain. Real Estate 2011, 3, 254-273. [CrossRef]

48. Rehm, M.; Ade, R. Construction costs comparison between 'green' and conventional office buildings. Buildi. Res. Inf. 2013, 41, 198-208. [CrossRef]

49. Falcone, M.P.; Imbert, E. Social Life Cycle Approach as a Tool for Promoting the Market Uptake of Bio-Based Products from a Consumer Perspective. Sustainability 2018, 10, 1031. [CrossRef]

50. Barker, G.; Odling-Smee, J. Integrating Ecology and Evolution: Niche Construction and Ecological Engineering. In Entangled Life: Organism and Environment in the Biological and Social Sciences; Barker, G., Desjardins, E., Pearce, T., Eds.; Springer: Dordrecht, The Netherlands, 2014; pp. 187-211. [CrossRef]

51. Horman, M.J.; Riley, D.R.; Lapinski, A.R.; Korkmaz, S.; Pulaski, M.H.; Magent, C.S.; Luo, Y.; Harding, N.; Dahl, P.K. Delivering Green Buildings: Process Improvements for Sustainable Construction. J. Green Build. 2006, 1, 123-140. [CrossRef]

(C) 2019 by the authors. Licensee MDPI, Basel, Switzerland. This article is an open access article distributed under the terms and conditions of the Creative Commons Attribution (CC BY) license (http://creativecommons.org/licenses/by/4.0/). 